\title{
Caesalpinioideae (Leguminosae) de um Remanescente de Chaco em Porto Murtinho, Mato Grosso do Sul, BrasiL ${ }^{1}$
}

\author{
Fábio de Matos Alves² \& Ângela Lúcia B. Sartori ${ }^{3}$
}

\section{Resumo}

(Caesalpinioideae (Leguminosae) de um remanescente de Chaco em Porto Murtinho, Mato Grosso do Sul, Brasil) Leguminosae apresenta-se como uma das famílias mais representativas do Chaco brasileiro, com destaque para Caesalpinioideae, segunda subfamília em número de espécies. Ainda assim, existem poucos levantamentos para essa região. Este estudo consiste no levantamento florístico de Caesalpinioideae em um remanescente de Chaco em Porto Murtinho, Mato Grosso do Sul. Foram realizadas coletas nas estações seca e chuvosa, para a obtenção de materiais férteis, por meio de caminhadas aleatórias. O presente estudo fornece chave de identificação dos táxons, descrições, ilustrações, comentários taxonômicos e dos ambientes preferenciais. Caesalpinioideae está representada por três tribos e 12 táxons: Bauhinia hagenbeckii, Caesalpinia paraguariensis, C. pluviosa, Chamaecrista nictitans subsp. disadena var. pilosa, C. rotundifolia var. rotundifolia, Parkinsonia praecox, Peltophorum dubium var. dubium, Pterogyne nitens, Senna pendula var. paludicola, S. pilifera var. pilifera, S. obtusifolia e S. occidentalis. Como espécies possivelmente restritas ao Chaco destacam-se Bauhinia hagenbeckii e Caesalpinia paraguariensis.

Palavras-chave: florística, Fabaceae, Neotrópico, savana estépica.

\section{Abstract}

(Caesalpinioideae (Leguminosae) of a Chaco remnant in Porto Murtinho, Mato Grosso do Sul, Brazil) Leguminosae is one of the most representative families of the Brazilian Chaco, with Caesalpinioideae as the second subfamily with more species. Nevertheless, there are few studies on the chaquenian portion of Brazil. This study is a floristic survey of the Leguminosae subfamily Caesalpinioideae in a Chaco remnant in Porto Murtinho, Mato Grosso do Sul. Field collections of fertile materials were made during the dry and the rainy season, using random sampling. This study presents identification key, descriptions, illustrations, habitat comments and taxonomy for each taxon. Caesalpinioideae is represented by three tribes and twelve taxa: Bauhinia hagenbeckii, Caesalpinia paraguariensis, C. pluviosa, Chamaecrista nictitans subsp. disadena var. pilosa, C. rotundifolia var. rotundifolia, Parkinsonia praecox, Peltophorum dubium, Pterogyne nitens, Senna pendula var. paludicola, S. pilifera var. pilifera, S. obtusifolia, and S. occidentalis. Bauhinia hagenbeckii and Caesalpinia paraguariensis are possibly restricted to the Chaco.

Key words: floristics, Fabaceae, Neotropics, stepic savannah.

\section{INTRODUÇÃo}

O Chaco é uma das maiores unidades fitogeográficas da América do Sul (Lewis 1991) e conta com uma área superior a $800.000 \mathrm{~km}^{2}$ de extensão, localizando-se da Argentina (norte), Paraguai (centro e oeste), Bolívia (sul) a uma pequena porção do Brasil, situada no sudoeste de Mato Grosso do Sul (Hueck 1972).

Embora existam estudos para o Chaco no Paraguai (Spichiger et al. 1991) e principalmente na Argentina (Adamoli et al. 1972; Lewis 1991), no Brasil estudos florísticos ainda são incipientes, o que reflete na defasagem do conhecimento da flora para esta formação vegetacional dentro do país. Dos poucos dados disponíveis sobre a florística das áreas chaquenhas no Mato Grosso do Sul destacam-se os estudos de Prado et al. (1992) e Nunes (2006).

Leguminosae é uma das famílias mais representativas da flora sul mato-grossense (Dubs 1998), onde se destaca em riqueza de espécies em diferentes formações vegetacionais

Artigo recebido em 07/2008. Aceito para publicação em 04/2009.

${ }^{1}$ Parte da dissertação de Mestrado do primeiro autor no Programa de Pós-graduação em Biologia Vegetal - Universidade Federal de Mato Grosso do Sul (UFMS).

2Programa de Pós-graduação em Biologia Vegetal - Universidade Federal de Mato Grosso do Sul (UFMS).

${ }^{3}$ Universidade Federal de Mato Grosso do Sul (UFMS), Centro de Ciências Biológicas e da Saúde (CCBS), Depto. Biologia (DBI), Laboratório de Botânica, Cidade Universitária, C.P. 549, 79070-900, Campo Grande, MS.

e-mail para contato: matos_fabio@yahoo.com.br; matosfabio@hotmail.com 
(Pott \& Pott 2003), tais como o Cerrado (Pott et al. 2006) e o Chaco (Nunes 2006).

Dubs (1998) cita 75 táxons de Caesalpinioideae, entre nativos e introduzidos, para Mato Grosso do Sul, sendo sete destes citados para Porto Murtinho. Em estudos mais recentes, direcionados a alguns remanescentes de Chaco em Porto Murtinho, Nunes (2006) relata 18 espécies de Caesalpinioideae em diferentes formações chaquenhas.

Na busca de aprimorar o conhecimento sobre o Chaco brasileiro ainda pouco explorado pela ciência, este estudo tem como principal objetivo o levantamento florístico de táxons de Caesalpinioideae ocorrentes em um remanescente com esta formação, em Porto Murtinho, apresentando chave de identificação, descrições, ilustrações, comentários taxonômicos e informações sobre distribuição geográfica.

\section{Materiale Métodos}

As expedições para coleta foram realizadas na fazenda Agro-Comercial Aubi (ex-São Roque), localizada entre as coordenadas geográficas $21^{\circ} 42^{\prime} 48.3^{\prime \prime}-21^{\circ} 40$ '05.6”S e 5741’15.8”-5740’53.9”W, município de Porto Murtinho, Mato Grosso do Sul (Fig. 1), nas estações úmida (fevereiro e dezembro) e seca (maio e agosto) de 2007. As coletas foram realizadas por meio de caminhadas aleatórias em remanescente, com cerca de 300 ha, de Savana Estépica (Chaco) conforme a classificação do IBGE (1992). Aárea estudada caracteriza-se predominantemente como savana estépica arbórea, com estratos arbóreoarbustivos (apresentando geralmente indivíduos com 2-4 m de altura) entremeados por estrato herbáceo, a savana estépica florestada pode ser encontrada nas bordas dos remanescentes.

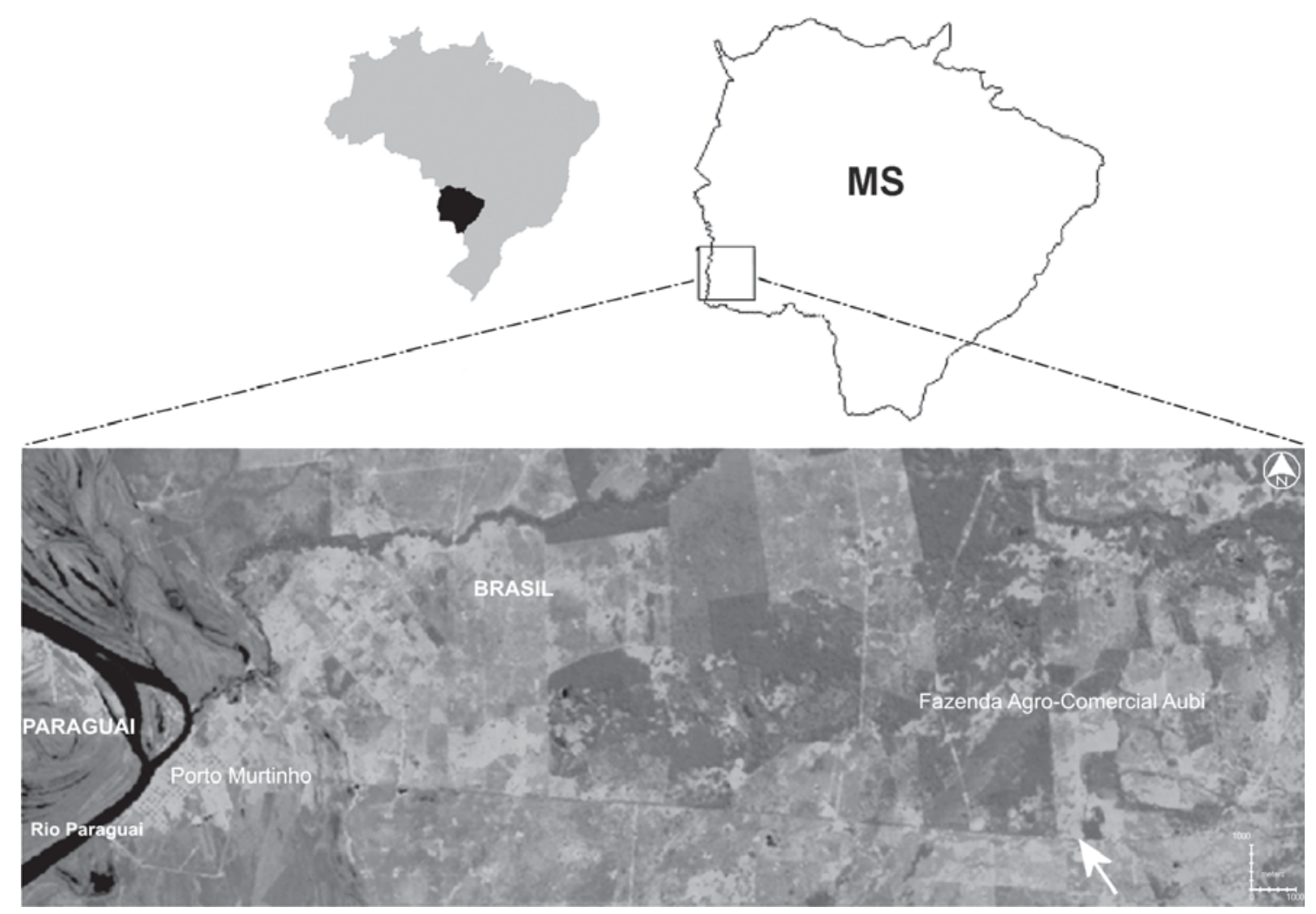

Figura 1 - Mapa do Brasil, com destaque para o estado de Mato Grosso do Sul e a região do município de Porto Murtinho, com área do remanescente indicada (seta) em imagem LANDSAT (ano 2000 na escala 1:60.000).

Figure 1 - Map of Brazil, showing Mato Grosso do Sul's state and Porto Murtinho's city, with the remnant area pointed (arrow). Image LANDSAT (2000, scale 1:60.000). 
Para esse remanescente tem-se informações de que a cerca de uma década foi retirada parte da vegetação, resultando em trechos com antropização mais acentuada e fragmentação da vegetação, o que dificulta, muitas vezes, uma caracterização mais precisa, considerando sobretudo a savana estépica florestada, ainda não estudada em território brasileiro.

Os materiais coletados, preferencialmente férteis, foram herborizados conforme a técnica descrita por Fidalgo \& Bononi (1984). As identificações foram realizadas com auxílio de literatura especializada, por consulta a especialistas, quando possível, e por comparações com materiais do Herbário CGMS.

As descrições basearam-se na amplitude de variação morfológica dos materiais coletados na área de estudo. A terminologia utilizada para os hábitos seguiu a classificação proposta por Guedes-Bruni et al. (2002), as determinações morfológicas das partes vegetativas e reprodutivas, bem como dos tipos de indumentos, foram baseadas em Rizzini (1977), Radford et al. (1974) e Stearn (2004), a classificação morfológica dos frutos seguiram a terminologia proposta por Barroso et al. (1999). As medidas das flores abrangem o comprimento do pedicelo e perianto, nos frutos o pedicelo não foi mensurado.

As ilustrações foram confeccionadas a partir do material coletado e herborizado, as estruturas florais passaram pelo processo de hidratação e foram ilustradas com auxílio de um estereomicroscópio.

\section{Resultados e Discussão}

Neste levantamento são registrados 12 táxons, pertencentes a três tribos: Caesalpinieae, com Caesalpinia L., Parkinsonia L., Peltophorum (Vogel) Walpers e Pterogyne Tul.; Cassieae, com Chamaecrista Moench e Senna Mill.; e Cercideae, com Bauhinia L. Os gêneros com o maior número de espécies são Senna (quatro), Caesalpinia (duas) e Chamaecrista (duas). Entre os táxons confirmados, o hábito arbóreo prevaleceu sobre os demais, com cinco representantes, seguido por três subarbustivos, dois arbustivos, um subarbustivo-herbáceo e um herbáceo.

Dentre as espécies confirmadas, Caesalpinia pluviosa DC., Peltophorum dubium (Spreng.) Taub., Pterogyne nitens Tul. e Senna pendula (Willd.) H.S. Irwin \& Barneby var. paludicola H.S. Irwin \& Barneby já haviam sido citadas para Porto Murtinho por Dubs (1998). Além destas, Nunes (2006) também registrou Caesalpinia paraguariensis (D. Parodi) Burkart, Chamaecrista rotundifolia (Pers.) Greene, Parkinsonia praecox (Ruiz \& Pav. ex Hook.) J. Hawkins, Senna occidentalis (L.) Link e Senna pilifera (Vogel) H.S. Irwin \& Barneby, para áreas chaquenhas em Porto Murtinho, sendo, Chamaecrista rotundifolia, Parkinsonia praecox, Peltophorum dubium, Senna pendula e Senna pilifera registradas para uma área de fitofisionomia semelhante a área do presente estudo. Portanto, Bauhinia hagenbeckii Harms, Chamaecrista nictitans subsp. disadena (Steud.) var. pilosa (Benth.) H.S. Irwin \& Barneby e Senna obtusifolia (L.) H.S. Irwin \& Barneby são novas citações para a flora de Porto Murtinho. Pode-se então afirmar que a flora de Caesalpinioideae nas formações de savana estépica arbórea de Porto Murtinho está composta atualmente por 21 táxons.

Bauhinia hagenbeckii (Wuderlin 1968; Vaz \& Tozzi 2005), Caesalpinia paraguariensis e Parkinsonia praecox (Adamoli et al. 1972; Hueck 1972; Prado et al. 1992; Spichiger et al., 1991; Fernandez 2003) são mencionados como característicos do Chaco, com o último táxon ocorrendo em áreas disjuntas na América (Hawkins et al. 1999). Bauhinia hagenbeckii e Caesalpinia paraguariensis são mencionados somente para a região sudoeste de Mato Grosso do Sul (Dubs 1998; Prado et al. 1992; Wuderlin 1968; Vaz \& Tozzi 2005), indicando possivelmente distribuição restrita ao Chaco.

Caesalpinia pluviosa (Killeen et al. 2006), Pterogyne nitens e Peltophorum dubium var. dubium ocorrem preferencialmente em florestas neotropicais sazonalmente secas (Prado \& Gibbs 1993; Barneby 1996). A 
ocorrência destas espécies possivelmente é devido às formações de florestas secas nas proximidades do remanescente estudado.

Senna pendula var. paludicola e $S$. pilifera var. pilifera ocorrem no sul da América do Sul (Irwin \& Barneby 1982), no Brasil, Paraguai, Argentina, Uruguai e Bolívia (exceto Senna pendula var. paludicola).

Chamaecrista nictitans subsp. disadena var. pilosa, C. rotundifolia var. rotundifolia encontram-se distribuídos em praticamente todo o continente americano, além de Senna obtusifolia e $S$. occidentalis presentes na África e Ásia (Irwin \& Barneby 1982).

\section{Caesalpinioideae}

Ervas, subarbustos, arbustos e árvores; estípulas presentes ou ausentes; estipelas ausentes; folhas pinadas, bipinadas, bifolioladas (Chamaecrista rotundifolia var. rotundifolia e Bauhinia hagenbeckii) raro unifolioladas (Bauhinia hagenbeckii), paripinadas (exceto Pterogyne nitens e Caesalpinia pluviosa); estruturas secretoras peciolares presentes ou ausentes; inflorescência geralmente em racemo terminal ou axilar; flores pentâmeras, geralmente "vistosas", zigomorfas ou actinomorfas (Pterogyne nitens), pediceladas; cálice dialissépalo ou gamossépalo (Bauhinia hagenbeckii); corola dialipétala; estames 510, dialistêmones, raro gamostêmones (Bauhinia hagenbeckii), anteras rimosas ou poricidas (Senna e Chamaecrista); ovário séssil ou estipitado, frutos tipo legume ou sâmara (Peltophorum dubium var. dubium e Pterogyne nitens).

\section{Chave para identificação dos táxons de Caesalpinioideae de um remanescente de Chaco em Porto Murtinho - Mato Grosso do Sul, Brasil}

1. Árvores ou arbustos

2. Ramos armados de acúleos

3. Folhas unifolioladas bilobadas a bifolioladas

7.1. Bauhinia hagenbeckii

3'. Folhas bipinadas

2.1. Parkinsonia praecox

2'. Ramos inermes

4. Folhas pinadas

5. Árvores; folhas geralmente imparipinadas; ausência de estrutura secretora nas folhas; flores menores que $1 \mathrm{~cm}$ compr.; fruto tipo sâmara.

4.1. Pterogyne nitens

5'. Arbustos; folhas sempre paripinadas; presença de estrutura secretora nas folhas; flores maiores que $2 \mathrm{~cm}$ compr.; fruto tipo legume bacóide

4'. Folhas bipinadas

6.3. Senna pendula var. paludicola

6. Folíolos rômbicos

1.2. Caesalpinia pluviosa

6'. Folíolos oblongos

7. Folha com 2-5 pares de pinas, 4-10 pares de folíolos; fruto tipo legume nucóide. 1.1. Caesalpinia paraguariensis

7'. Folha com 6-15 pares de pinas; 12-27 pares de folíolos; fruto tipo sâmara 3.1. Peltophorum dubium var. dubium

1'. Ervas ou subarbustos

8. Hábito ereto

9. Folhas com 9-21 pares de folíolos, nervura principal geralmente excêntrica; estrutura secretora peciolar caliciforme 
9'. Folhas com 2-6 pares de folíolos, nervura principal cêntrica; estrutura secretora capitada 10. Folhas com 2-3 pares de folíolos, folíolos obovados; estrutura secretora peciolar entre o primeiro par de folíolos 6.1. Senna obtusifolia 10'. Folhas com 4-6 pares de folíolos, folíolos estreito-elípticos a estreito-ovados; estrutura secretora peciolar na base do pecíolo 6.2. Senna occidentalis

8'. Hábito decumbente

11. Folhas bifolioladas, folíolos obovados; estrutura secretora peciolar ausente; androceu com 5 estames 5.2. Chamaecrista rotundifolia var. rotundifolia

11'. Folhas pinadas, outras formas de folíolos; estrutura peciolar capitada entre os pares de folíolos; androceu com 7 estames.. 6.4. Senna pilifera var. pilifera

\section{Tribo Caesalpinieae Rchb.}

\section{Caesalpinia L.}

Árvores, arbustos, ou lianas; folhas bipinadas, raro pinadas; flores zigomorfas (Ulibarri 1996); legume deiscente ou indeiscente (Bacigalupo 1987). O gênero encontra-se distribuído em florestas, bosques ou semi-desertos da América, África e Ásia. Caesalpinia s.l. possui cerca de 150 espécies, sendo 40 sul-americanas (Ulibarri 1996). As espécies registradas neste estudo são Caesalpinia paraguariensis e C. pluviosa.

\subsection{Caesalpinia paraguariensis (D. Parodi)} Burkart, Darwiniana 10(1): 26. 1952. Fig. 2

Árvore, ca. 5-10 m alt.; ramo cilíndrico, estriado, inerme, glabro, lenticelado. Estípulas ausentes. Folha bipinada, 4,2-7,2 cm compr.; 2-5 pares de pinas, opostas, raro alternas; 4-10 pares de folíolos opostos, terminais paripinados; estrutura secretora peciolar ausente; pecíolo e raque não suturados, glabro; folíolo 4-9,1 $\times$ 1,9-4 mm, glabro, oblongo, terminal obovado, ápice obtuso, raro retuso, base oblíqua, margem inteira, discolor, venação hipódroma, nervura principal cêntrica. Inflorescência em racemo terminal, ca. 6-15 flores; brácteas caducas, orbiculares, dorsalmente puberulenta; bractéolas ausentes; pedúnculo livre. Flor 1,3-1,6 cm compr.; cálice glabro, margem inteira, sépalas heteromórficas, elípticas a oblongas; corola amarela, pétala vexilar com manchas avermelhadas, face ventral com tricomas capitados na base da pétala, pétalas heteromórficas, ovais a elípticas, ungüiculadas; estames 10 , isodínamos, filete com tricoma secretor capitado; ovário estipitado, glabro, estilete reto, glabro, estigma truncado seríceo. Legume nucóide, 3,1-3,7 × 1,8-2 cm, oblongo, ápice e base arredondados, imaturo verde, maduro castanho-escuro, indeiscente, glabro, rostelo cêntrico; sementes 3, elipsóides, pretas, ruminadas, suturadas.

Material examinado: 28.VIII.2007, fr., F.M. Alves et al. 461 (CGMS); 4.XII.2007, fr., F.M.Alves \&A.L.B. Sartori 488 (CGMS); 4.XII.2007, fl. e fr., F.M. Alves \& A.L.B. Sartori 501(CGMS).

Caesalpinia paraguariensis tem registros para regiões de bosques úmidos ou xerófilos da Bolívia, Paraguai, Brasil e Argentina (Ulibarri 1996). Espécie característica da província do Chaco (Prado et al. 1992). É facilmente reconhecida por apresentar folhas bipinadas, pinas geralmente opostas; folíolos opostos, terminais paripinados, oblongos; pétalas ovais a elípticas; fruto oblongo com extremidades arredondadas; além de apresentar caule esfoliante. Na área de estudo foram observados poucos indivíduos entremeados ao estrato arbóreo/arbustivo mais denso.

1.2. Caesalpinia pluviosa DC., Prodr. 2: 483. 1825.

Fig. 3

Árvore, ca. 2,5-6 m alt.; ramo cilíndrico, estriado, inerme, puberulento, lenticelado. Estípulas ausentes. Folha bipinada, 7-22 cm compr.; 5-11 pares de pinas, alternas a opostas; 5-16 pares de folíolos, geralmente alternos, terminais pari ou imparipinados; estrutura secretora peciolar ausente; pecíolo 


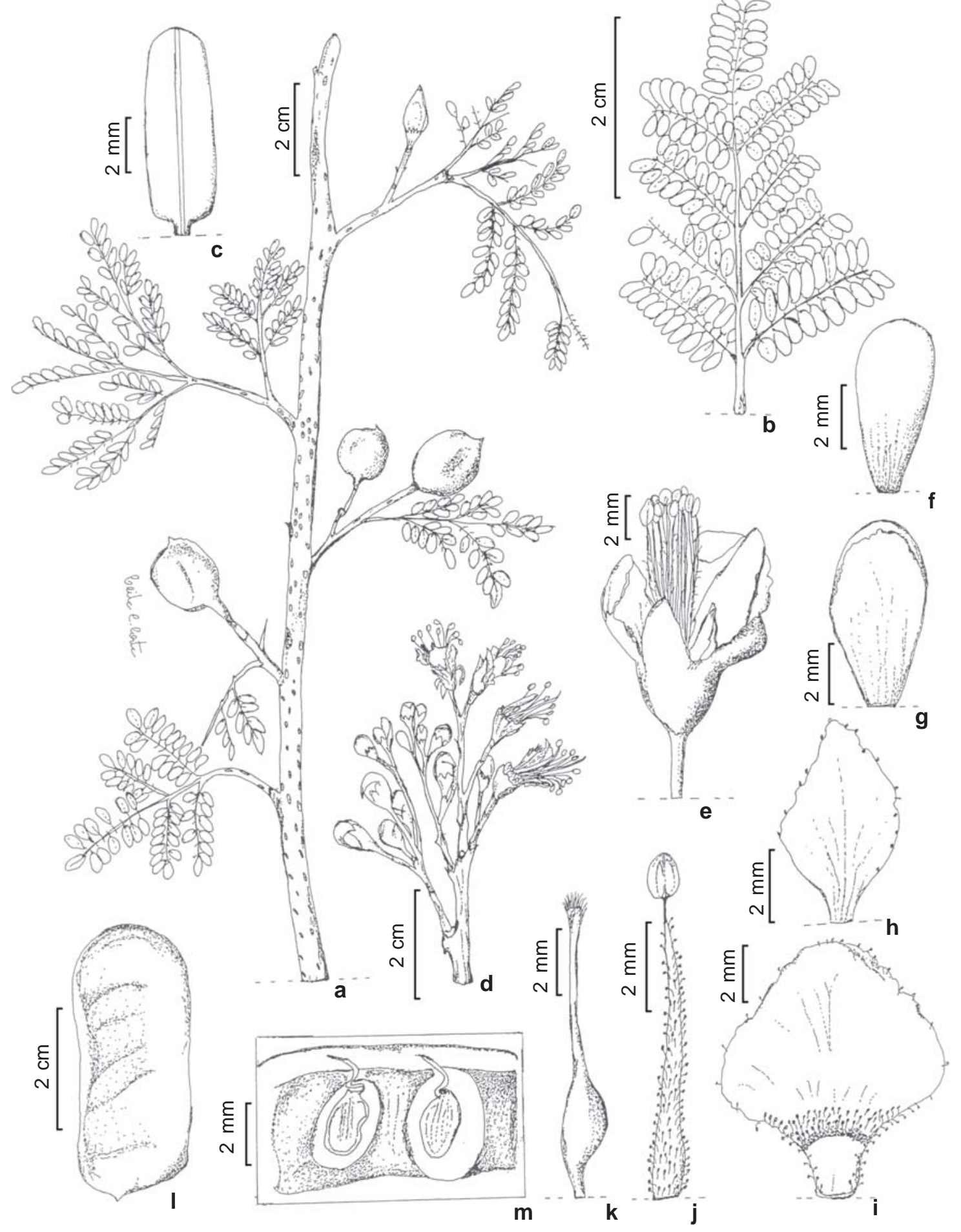

Figura 2 - Caesalpinia paraguariensis(D. Parodi) Burkart -a. ramo; b. folha; c. folíolo; d. inflorescência; e. flor; f-g. sépalas; h-i. pétalas; j. estame; k. carpelo; l. fruto; m. semente com inserção no fruto (Alves et al. 275).

Figure 2 - Caesalpinia paraguariensis (D. Parodi) Burkart - a. branch; b. leaf; c. leaflet; d. inflorescence; e. flower; f-g. sepals; h-i. petals; j. stamen; k. gynoecium; l. fruit; m. detail of fruit, showing the seeds (Alves et al. 275). 


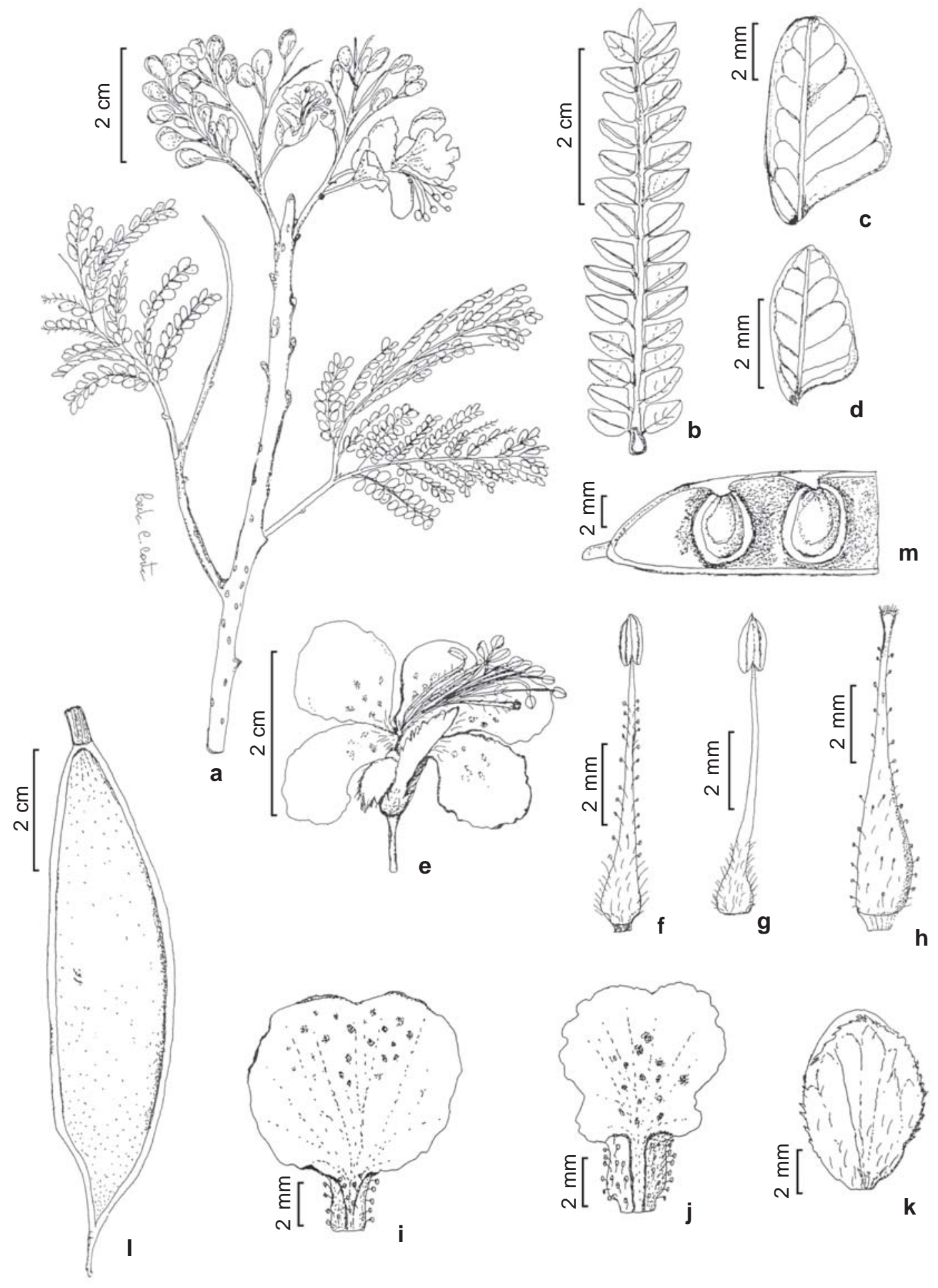

Figura 3 - Caesalpinia pluviosa DC. - a. ramo; b. pina; c-d. folíolo; e. flor; f-g. estames; h. carpelo; i-j. pétalas; k. sépala; 1. fruto; m. semente com inserção no fruto (Alves et al. 265).

Figure 3 - Caesalpinia pluviosa DC. - a. branch; b. pinna; c-d. leaflet; e. flower; f-g. stamen; h. gynoecium; i-j. petals; k. sepal; l. fruit; m. detail of fruit, showing the seeds (Alves et al. 265). 
e raque não suturados, indumento pubescente e glandular; folíolo 3,7-12,4 × 2-6,4 mm, glabrescente, glandular na face abaxial, rômbico-assimétrico, ápice obtuso a levemente truncado, base oblíqua, margem ciliada, discolor, venação broquidódroma, nervura principal excêntrica. Inflorescência em racemo ou panícula, terminal, multiflorada; brácteas caducas, triangulares, velutinas; bractéolas ausentes; pedúnculo livre. Flor 1,8-3,5 cm compr.; cálice puberulento, margem fimbriada, sépalas isomórficas, ovadas; corola amarela, pétala vexilar com manchas avermelhadas ou não, pétalas heteromórficas, obovada a largoelípticas, ungüiculadas com tricomas capitados; estames 10, isodínamos, filete barbado, com tricoma capitado ou não; ovário curtoestipitado, com denso indumento seríceo e capitado, estilete reto, com esparso indumento seríceo e capitado. Legume, 6,1-11,3 × 1,32,3 cm, oblongo a obovado, ápice e base atenuados, imaturo verde, maduro acastanhado, deiscente, puberulento, rostelo cêntrico; sementes 5, ovóides, achatadas, acastanhadas, lisa com depressão central.

Material examinado: 16.II.2007, fl. e fr., F.M.Alves et al. 66 (CGMS); 16.II.2007, fl. e fr., F.M.Alves et al. 265 (CGMS); 17.II.2007, fr., F.M. Alves etal.39(CGMS); 8.V.2007, fl., F.M.Alves et al.370(CGMS); 28.VIII.2007, fl. e fr., F.M. Alves et al. 458(CGMS); 4.XII.2007, fl., F.M.Alves \& A.L.B. Sartori 483(CGMS).

Caesalpinia pluviosa distribui-se em regiões de floresta na porção oriental da Bolívia, Paraguai, Brasil e norte da Argentina (Ulibarri 1996). Espécie reconhecida pelos folíolos geralmente alternos, rômbicoassimétricos, terminais geralmente imparipinados; pétalas obovadas a largo-elípticas, fruto oblongo a obovado com extremidades nunca arredondadas. Os indivíduos jovens encontrados na área, apresentavam folíolos com até 3,25 × 1,5 cm, este tamanho bem superior do padrão do indivíduo adulto pode gerar confusões nas identificações quando o material estiver estéril. Esta espécie ocorre principalmente em locais do remanescente onde predomina o componente arbóreo/arbustivo aberto.

\section{Parkinsonia L.}

Árvores ou arbustos (Hawkins et al. 1999; Lewisetal. 2005); folhas bipinadas, folíolos pequenos e caducos; racemos paucifloros; legumes deiscentes sem elasticidade (Bacigalupo 1987). Parkinsonia apresenta cerca de 1112 espécies distribuídas nas Américas e África, em regiões tropicais e subtropicais, nos ambientes áridos, sazonalmente secos, semideserto, costas de dunas e planícies inundáveis. A maioria das espécies encontra-se no Deserto de Sonora (México) e no sul dos Estados Unidos (Burkart \& Carter 1976; Hawkins et al. 1999; Lewis et al. 2005). Neste estudo foi coletada a espécie Parkinsonia praecox.

2.1. Parkinsonia praecox (Ruiz \& Pav. ex Hook.) J. Hawkins, Pl. Syst. Evol. 216: 63. 1999.

Fig. 4

Árvore, ca. 2,5-3 m alt.; ramo cilíndrico, estriado, armado, glabrato, lenticelado. Estípula transformada em acúleo. Folha bipinada, 1,74,8 cm compr., distribuída em fascículos alternos; 1-2 pares de pinas, opostas; 6-9 pares de folíolos opostos, terminais paripinados; estrutura secretora peciolar ausente; pecíolo e raque suturados na face dorsal, pubescente, acúleo terminal uncinado; folíolo 4,5-9,5×1,62,6 mm, face adaxial glabrescente, face abaxial pubescente, elíptico a oblanceolado, mucronado, base obtusa, margem inteira, discolor, venação hipódroma, nervura principal cêntrica. Inflorescência em racemo, axilar, 3-7 flores; bráctea triangular, pubescente; bractéola ausente; pedúnculo livre. Flor 1,5-2,1 cm compr.; cálice, glabrato, margem inteira, barbado no ápice, sépalas isomórficas, estreitoelípticas; corola amarela, pétala vexilar com manchas avermelhadas, glabra, pétalas heteromórficas, rômbicas, (largo-)elípticas e circulares, ápice arredondado, ungüícula ventralmente pubescente; estames 10 , isodínamos, pubescentes na região medianabasal; ovário estipitado, glabro, estilete encurvado, glabro. Legume estreito-elíptico a linear, reto, 3,7-9,3 × 0,5-0,8 cm, imaturo 

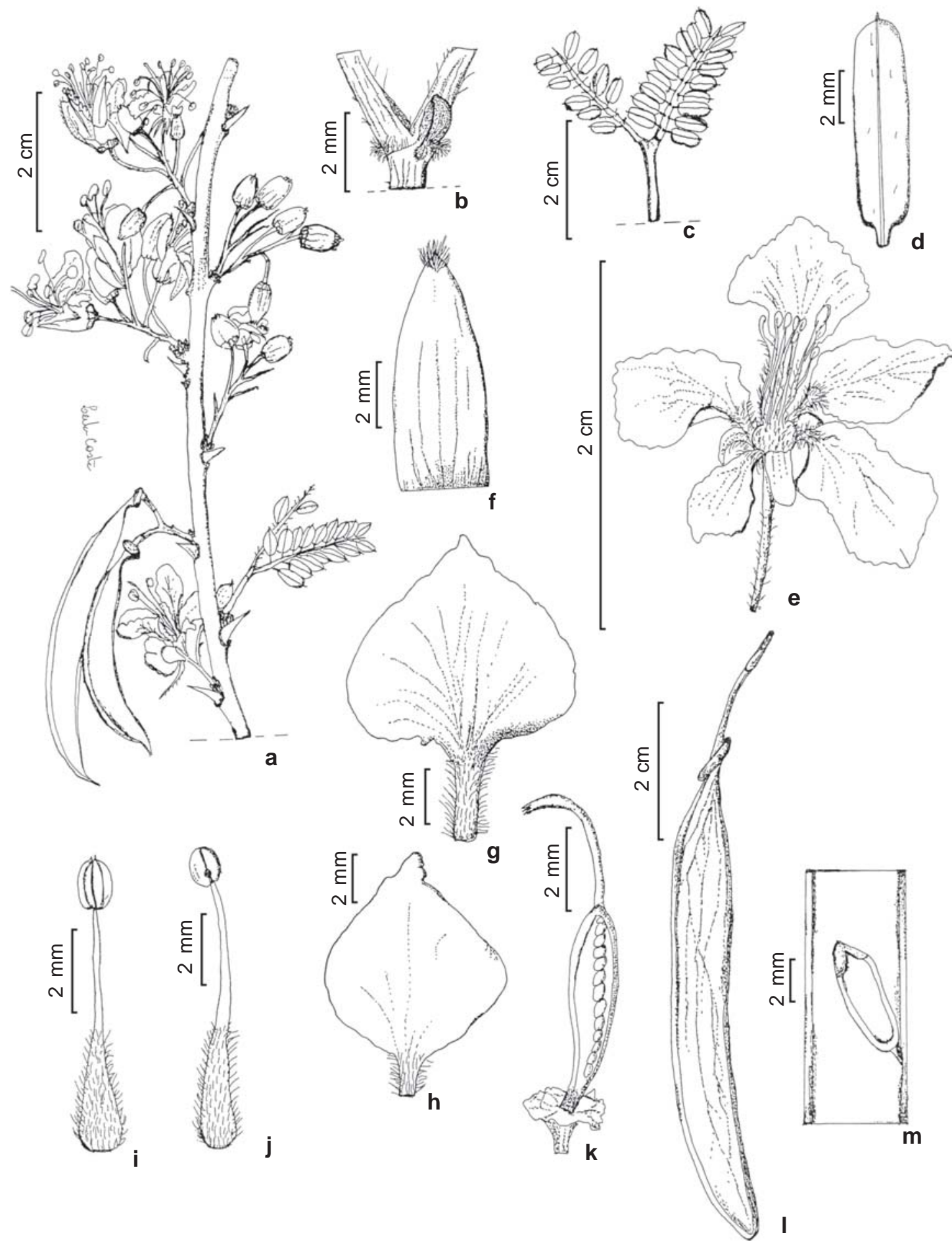

Figura 4 - Parkinsonia praecox (Ruiz \& Pavon ex Hook.) J. Hawkins - a. ramo; b. raque com acúleo terminal uncinado; c. folha; d. folíolo; e. flor; f. sépala; g-h. pétalas; i-j. estames; k. carpelo; l. fruto; m. semente com inserção no fruto (Alves et al. 346).

Figure 4 - Parkinsonia praecox (Ruiz \& Pavon ex Hook.) J. Hawkins - a. branch; b. rachis with terminal uncinated aculeus; c. leaf; d. leaflet; e. flower; f. sepal; g-h. petals; i-j. stamen; k. gynoecium; l. fruit; m. detail of fruit, showing the seeds (Alves et al. 346). 
vináceo, maduro acastanhado, aparentemente indeiscente, glabro, rostelo cêntrico, sementes 1-5, oblongas, planas, castanho-esverdeadas, semi-transparentes, borda espessa, lineata.

Material examinado: 8.V.2007, fl. e fr., F.M. Alves et al. 346 (CGMS); 8.V.2007, fl., F.M. Alves et al. 361 (CGMS); 9.V.2007, fl., F.M. Alves et al. 378(CGMS); 29.VIII.2007, fl. e fr., F.M. Alves \& A.L.B. Sartori 469 (CGMS).

Parkinsonia praecox ocorre no centro e norte da Argentina, oeste e norte da América do Sul (Peru, Equador e Venezuela) até o México e Califórnia (Burkart \& Carter 1976; Hawkins et al. 1999). É uma espécie característica de Chaco (Prado et al. 1992). Segundo Burkart \& Carter (1976), Cercidium praecox (Ruiz \& Pav.) Harms, atualmente tratada como Parkinsonia praecox, apresenta semelhança com Cercidium praecox(Ruiz \& Pav.) Harms subsp. glaucum (Cav.) Burkart \& Carter, restrita à Argentina. Na área de estudo, Parkinsonia praecox é facilmente reconhecida por apresentar caule de coloração verde-oliva, ramos armados de acúleos; folhas bipinadas com tamanho reduzido (ca. 2-5 cm) e um ou dois pares de pinas opostas. É uma espécie muito comum, sendo dominante em grande parte da área de estudo.

\section{Peltophorum (Vogel) Walpers}

Árvores; folhas bipinadas, multifolioladas; sâmara com uma a três sementes (Bacigalupo 1987). Peltophorum possui cerca de cinco a sete espécies, pantropicais, sendo duas nativas nos neotrópicos (Lewis et al. 2005). Peltophorum dubium var. dubium é a única espécie do gênero registrada para o Brasil (Barneby 1996).

3.1. Peltophorum dubium (Spreng.) Taub. var. dubium, Nat. Pflanzenfam.3(3): 176. 1892.

Fig. 5a-d

Árvore, ca. 10-12 m alt.; ramo cilíndrico, estriado, inerme, glabrescente, lenticelado. Estípulas ausentes. Folha paribipinada, 16-31,8 cm compr.; 6-15 pares de pinas, opostas; 12-27 pares de folíolos, opostos; estrutura secretora peciolar ausente; pecíolo e raque dorsalmente suturados, indumento capitado, tomentoso/ viloso-ferrugíneo; folíolo 4,1-15×2-4,3 mm, glabrato (adaxial), esparso-pubescente adpresso (abaxial), oblongo, ápice acuminado, base oblíqua, margem inteira, discolor, venação broquidódroma inconspícua, nervura principal cêntrica. Inflorescência em racemo terminal, multiflorada; bráctea caduca, estreitotriangular, esparso-velutina na face dorsal; bractéolas ausentes; pedúnculo livre. Flor 2,33 cm compr.; cálice pubescente-ferrugíneo, margem fimbriada, sépalas isomórficas, ovadas; corola amarela, barbada-ferrugínea, pétalas heteromórficas, oblongas, ungüiculadas; estames 10, isodínamos, filete barbadoferrugíneo; ovário estipitado, viloso-ferrugíneo; estilete curvado, esparso-viloso. Sâmara, 5,3$9 \times 1,19-1,74$ cm, elíptica, madura castanhoescura a acinzentada, indeiscente, pubescente a glabrato, rostelo ausente; sementes 1-2, oblongas, achatadas, bege, lisa ou com suturas transversais a reticuladas.

Material examinado: 17.II.2007, fr., F.M. Alves et al. 63(CGMS); 8.V.2007, fr, F.M.Alves et al.367(CGMS); 10.V.2007, fr, F.M.Alves et al. 421(CGMS); 4.XII.2007, fl. e fr., F.M. Alves \&A.L.B. Sartori 500 (CGMS).

Peltophorum dubium var. dubium ocorre na Venezuela (florestas sazonais), Brasil (caatingas, florestas mesófilas), nordeste da Argentina, leste do Paraguai, (sem registro de coletas no Chaco) e Bolívia (Prado \& Gibbs 1993; Barneby 1996). Peltophorum dubium var. dubium é reconhecida por apresentar folhas bipinadas, pinas sempre opostas, folíolos oblongos, inflorescência com indumento pubescente-ferrugíneo, sâmara elíptica com uma ou duas sementes. No remanescente estudado, ocorre na borda, onde predomina o estrato arbóreo com ca. de 6-8 m de altura.

\section{Pterogyne Tul.}

Árvores, folhas geralmente imparipinadas, folíolos brilhantes na face adaxial; flores inconspícuas, actinomorfas; fruto sâmara com uma semente (Bacigalupo 1987). Gênero de 


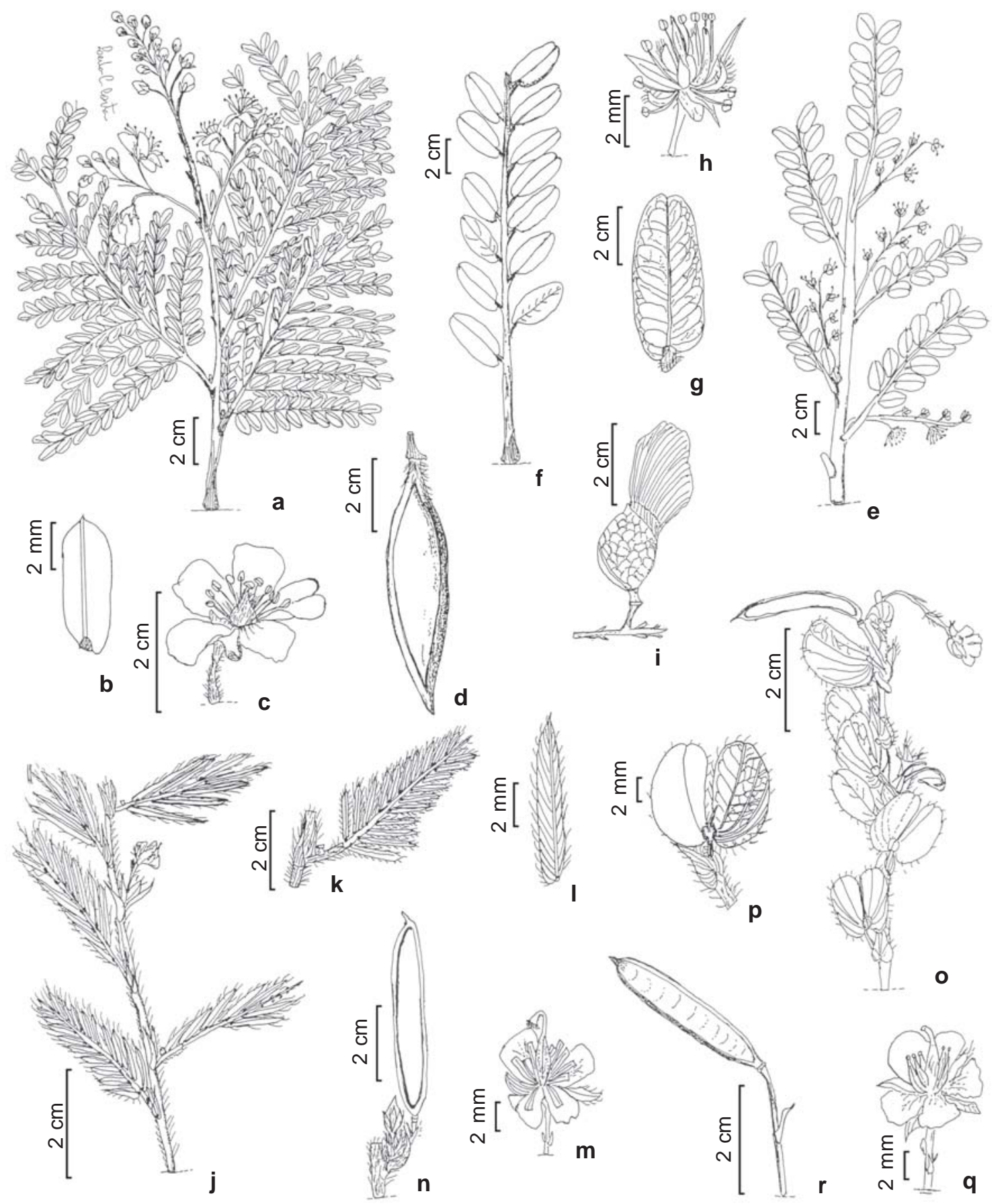

Figura 5 - a-d. Peltophorum dubium var. dubium (Spreng.) Taub. - a. ramo; b. folíolo; c. flor; d. fruto. e-i. Pterogyne nitens Tulasne - e. ramo; f. folha; g. folíolo; h. flor; i. fruto. j-n. Chamaecrista nictitans (L.) Moench subsp. disadena (Steudel) H.S. Irwin \& Barneby var. pilosa (Benth.) H.S. Irwin \& Barneby - j. ramo; k. folha; l. folíolo; m. flor; n. fruto. or. Chamaecrista rotundifolia var. rotundifolia (Pers.) Greene - o. ramo; p. folha; q. flor; r. fruto. (a-c Alves et al. 500; d Alves et al. 367; e-i Alves et al. 362; j-n Alves et al. 422; o-r Alves et al. 272).

Figure 5 - a-d. Peltophorum dubium var. dubium (Spreng.) Taub. - a. branch; b. leaflet; c. flower; d. fruit. e-i. Pterogyne nitens Tulasne - e. branch; f. leaf; g. leaflet; h. flower; i. fruit. j-n. Chamaecrista nictitans (L.) Moench subsp. disadena (Steudel) H.S. Irwin \& Barneby var. pilosa (Benth.) H.S. Irwin \& Barneby - j. branch; k. leaf; l. leaflet; m. flower; n. fruit. or. Chamaecrista rotundifolia var. rotundifolia (Pers.) Greene - o. branch; p. leaf; q. flower; r. fruit. (a-c Alves et al. 500, d Alves et al. 367; e-i Alves et al. 362; j-n Alves et al. 422; o-r Alves et al. 272). 
apenas uma espécie, Pterogyne é nativo da América do Sul, distribuído em áreas tropicais e subtropicais sazonalmentes secas (Lewis et al. 2005).

4.1. Pterogyne nitens Tul., Ann. Sci. Nat. Bot., sér. 2, 20: 140. 1843.

Fig. 5e-i

Árvore, ca. 2,5-5 m alt.; ramo cilíndrico, levemente estriado, inerme, glabro, puberulento a flocoso, lenticelado. Estípulas ausentes. Folha imparipinada, raro paripinada, 6,5-25 cm compr., 4-15 folíolos alternos, raro opostos, estrutura secretora ausente; pecíolo e raque levemente suturados na face dorsal, glabrescentes; folíolo 2-6×0,9-2,5 cm, glabrescente, estreito-elíptico ou elíptico, raro oblato, ápice geralmente retuso, raro arredondado e obcordado, base oblíqua, margem inteira, discolor, venação broquidódroma, inconspícua, nervura principal cêntrica. Inflorescência em racemo fasciculado ou paniculado, axilar, multiflorada; bráctea caduca, ovadas a largo-ovadas, dorsalmente velutina na face dorsal; bractéolas ausentes; pedúnculo livre. Flor 4-6,5 mm compr.; cálice barbado, margem ciliada, sépalas heteromórficas, elípticas a ovadas; corola amarelada, glabras, pétalas heteromórficas, estreito-elípticas a estreitooblongas, sésseis; estames 10, isodínamos, glabros; ovário estipitado, esparso-seríceo; estilete excêntrico, reto, glabrato. Sâmara, 3,54,7 ×1-1,3 cm, madura acastanhada, indeiscente, subglabrata, rostelo periférico; semente 1 , obovóide a elipsóide, achatada, acastanhada, punticulata e lineolata.

Material examinado: 17.II.2007, fr., F.M. Alves et al. 57 (CGMS); 8.V.2007, fl. e fr, F.M. Alves et al. 362 (CGMS).

Pterogyne nitens ocorre no Brasil (caatinga, floresta atlântica da Região Sudeste e áreas do Sistema Paraguai-Paraná); Argentina, Paraguai e Bolívia (Lewis et al. 2005) nas florestas Piedmontes sub-Andinas e nas comunidades de florestas de galeria e florestas úmidas dentro do Chaco (Prado \& Gibbs 1993). Pterogyne nitens é reconhecida por apresentar folhas geralmente imparipinadas, folíolos brilhantes na face adaxial; flores inconspícuas; sâmara com uma semente. É uma espécie relativamente abundante na área de estudo, ocorrendo nas formações arbustivoarbóreas, onde pode até formar populações dominantes.

\section{Tribo Cassieae Bronn}

\section{Chamaecrista Moench}

Ervas, arbustos ou árvores; nectários extraflorais quando presentes cupuliformes, caliciformes ou pateliforme; folhas bifolioladas ou pinadas (Camargo \& Miotto 2004); pedicelos com 2 bractéolas proximais ou distais; flores em dois ciclos de estames, anteras de diferentes alturas, poricidas; legume elasticamente deiscente, valvas em espiral. Chamaecrista conta com ca. 265 espécies, tropicais, poucas extratropicais, sendo 239 nativas das Américas (Irwin \& Barneby 1982). Neste levantamento, os representantes do gênero foram Chamaecrista nictitans subsp. disadena var. pilosa e Chamaecrista rotundifolia var. rotundifolia.

5.1. Chamaecrista nictitans subsp. disadena (Steud.) var. pilosa (Benth.) H.S. Irwin \& Barneby, Mem. New York Bot. Gard. 35: 829. 1982.

Fig. 5j-n

Erva a subarbusto ereto, ca. 0,2-0,5m alt.; ramo cilíndrico, levemente estriado, ápice anguloso, inerme, pubescente e setoso. Estípula persistente, lanceolada, glabra, margem ciliada, paralelinérvea a levemente campilódroma. Folha paripinada ca. 2-6 cm compr., 9-21 pares de folíolos opostos, estrutura secretora peciolar caliciforme; raque setosa, suturada na face dorsal; folíolo 0,5-1,5 × 0,1-0,2 cm, geralmente glabro a pubescente, estreitooblongo ou estreito-elíptico a oblanceolado, ápice mucronado, base oblíqua, margem ciliada, discolor, venação eucamptódroma, nervura principal geralmente excêntrica. Inflorescência em racemo fasciculado, aparentemente supra-axilar (pedúnculo adnato ao caule), 1-2 flores; brácteas e bractéolas 
lanceoladas, geralmente opostas, pedúnculo adnato ao caule. Flor 1-1,3 cm compr.; cálice pubescente, margem inteira, sépalas isomórficas, lanceoladas; corola amarela, glabra, pétalas heteromórficas, obovadas e amplamente depressa-obovadas, ungüículas ornamentadas; estames 10, heterodínamos, glabros; ovário séssil, seríceo, estilete curvado, glabro. Legume linear-oblongo, 33-54× 3,6$4,3 \mathrm{~mm}$, imaturo verde e maduro castanho-claro, deiscente, pubescente, rostelo excêntrico; sementes 9-17, oblongas a largo-oblongas, achatadas, acastanhadas, foveata linear.

Material examinado: 16.II.2007, fl., F.M. Alves et al. 11 (CGMS); 9.V.2007, fl. e fr., F.M. Alves et al. 401 (CGMS); 10.V.2007, fl. e fr., F.M. Alves et al. 422 (CGMS).

Segundo Irwin \& Barneby (1982), Chamaecrista nictitans subsp. disadena var. pilosa é uma espécie de ampla distribuição, desde o México, América Central, Venezuela, Equador, Peru, Brasil, Paraguai e Bolívia. Tem ocorrência em diversas formações vegetacionais tais como campos, regiões costeiras e áreas ruderais. É caracterizada por apresentar estrutura secretora peciolar caliciforme, folíolos com a nervura principal geralmente excêntrica e estilete curvado. Na área de estudo, o táxon é encontrado onde o estrato herbáceo é dominante.

\subsection{Chamaecrista rotundifolia var.} rotundifolia, Mem. New York Bot. Gard., 35: 731. 1982.

Fig. 50-r

Subarbusto decumbente, ca. 0,3 m compr.; ramo cilíndrico, levemente estriado, ápice anguloso, inerme, pubescente. Estípula persistente, lanceolada a ovada, sagitada, glabra, margem ciliada, campilódroma. Folha bifoliolada, 4,5-26 mm, mucronada, estrutura secretora peciolar ausente; pecíolo suturado na face dorsal; folíolo 3,9-22 ×2,3-14,2 mm, glabro, obovado, ápice arredondado a retuso, raro mucronado, base oblíqua, margem ciliada, concolor, venação acródroma, nervura principal excêntrica. Inflorescência em racemo fasciculado, axilar a levemente supra-axilar, 12 flores; bráctea caduca, lanceolada aguda a caudada, ciliada; bractéolas lanceoladas, geralmente alternas; pedúnculo (quando presente) adnato ao caule. Flor ca. 2,3-4 cm; cálice pubescente, margem inteira, sépalas isomórficas, elípticas; corola amarela, glabra, pétalas heteromórficas, obovadas e largoobovadas, ungüículadas ornamentadas; estames 5, isodínamos, glabros; ovário séssil, seríceo, estilete curvado, glabro. Legume estreito-oblongo a linear-oblongo, 1,5-3,4 $\times$ $0,3-0,4 \mathrm{~cm}$, imaturo verde e maduro castanho (escuro), deiscente, pubescente, rostelo centralizado a excêntrico; sementes 4-12, cúbicas a oblongas, achatadas, acastanhadas, com pontos pálidos translúcidos.

Material examinado: 16.II.2007, fl. e fr., F.M.Alves et al. 272 (CGMS).

Chamaecrista rotundifolia var. rotundifolia é mais amplamente distribuída que $C$. nictitans subsp. disadena var. pilosa, ocorrendo desde os Estados Unidos até o Uruguai. Esta espécie tem registros para savanas, campos e áreas ruderais, sendo resistente a cortes e pastagens, ocupando preferencialmente áreas menos arborizadas (Irwin \& Barneby 1982). Chamaecrista rotundifolia var. rotundifolia é caracterizada por apresentar folhas bifolioladas presentes em todos os nós, ramos decumbentes, ausência de glândulas, cinco estames férteis, pedicelos longos (ca. 2-4 cm). É uma espécie incomum na área de estudo, presente em locais com estrato herbáceo dominante.

\section{Senna Mill.}

Ervas, lianas, subarbustos, arbustos ou árvores; pedicelos sem bractéolas; estrutura secretora peciolar capitada; folhas paripinadas, raro escamiforme; androceu zigomórfico, anteras poricidas; legume deiscente ou indeiscente, valvas com separação não em espiral. Senna agrega cerca de 260 espécies, tropicais, poucas extratropicais, sendo $4 / 5$ nativas das Américas (Irwin \& Barneby 1982). 
Neste levantamento foram identificados Senna pendula var. paludicola, Senna pilifera var. pilifera, Senna obtusifolia e Senna occidentalis.

6.1. Senna obtusifolia (L.) H.S. Irwin \& Barneby, Mem. New York Bot. Gard. 35: 252. 1982.

Fig. 6 a-c

Subarbusto ereto, ca. 0,5 m alt.; ramo cilíndrico, estriado, inerme, glabro a pubescente. Estípula caduca, estreito-triangular, margem ciliada, glabrescente, nervação hipódroma. Folha paripinada, 1,1-4,5 cm compr., 2-3 pares de folíolos opostos, estrutura secretora peciolar capitada no primeiro par de folíolos; pecíolo e raque suturados na face dorsal, pubescentes; folíolo $0,4-2 \times 0,3-1,2 \mathrm{~cm}$, adaxial glabro, abaxial pubescente, obovado, ápice arredondado a truncado, raro agudo, base oblíqua, margem ciliada, discolor, venação broquidódroma imperfeita, nervura principal cêntrica. Inflorescência em racemo, axilar, 1(2) flores; bráctea caduca, estreito-triangular, ciliada, glabrescente, bractéola ausente, pedúnculo livre. Flor ca. 1,5-1,7 cm compr.; cálice glabrescente, com manchas vináceas, margem ciliada, sépalas heteromórficas, elípticas e ovadas; corola amarela, glabrescente, pétalas heteromórficas, obovadas, ápice arredondado a obcordado, ungüiculadas; estames 7, heterodínamos, glabros, estaminódios 3; ovário séssil, encurvado, seríceo, estilete reto, glabro. Legume linear-falcado, 9,1-12,5 cm $\times$ 2,6-3,4 mm, imaturo verde, maduro castanho acinzentado, deiscente, híspido capitado, rostelo cêntrico, sementes 17-31, retangular-rômbicas, cilíndricas, verde-acastanhadas a castanhas, granuladas com nervuras soltas, areolada.

Material examinado: 9.V.2007, fl. e fr., F.M. Alves et al. 377 (CGMS).

Senna obtusifolia é provavelmente nativa das Américas, sendo encontrada em áreas tropicais e temperadas da Ásia e das Américas do Norte e Sul. Ocorre em beira de lagos, barrancos, leitos fluviais, colonizadora de pastagens e áreas ruderais (Irwin \& Barneby 1982). S. obtusifolia é facilmente distinta das demais espécies constatadas na área, por apresentar folhas com dois a três pares de folíolos, estrutura secretora peciolar capitada no primeiro par de folíolos, folíolos obovados e legume linear falcado. Esta espécie foi coletada em áreas antropizadas e borda de estrada.

6.2. Senna occidentalis (L.) Link, Handbuch 2: 140.1831.

Fig. 6 d-f

Erva ereta, са. 0,5-1 m alt.; ramo cilíndrico, ápice anguloso, estriado, inerme, glabro. Estípula ausente. Folha paripinada, 11,5-16,5 cm compr., 4-6 pares de folíolos opostos, estrutura secretora peciolar capitada na base do pecíolo; pecíolo e raque suturados na face dorsal, glabrescentes; folíolo 3-6,5 $\times$ 1,5-2,5 cm, glabro, estreito-elíptico a estreitoovado, ápice agudo a mucronado, base oblíqua, margem ciliada, discolor, venação broquidódroma, nervura principal cêntrica. Inflorescência em racemo, axilar a terminal, 1-3 flores; bráctea caduca, lanceolada, inteira, glabra; bractéola ausente, pedúnculo livre. Flor 1,5-2,5 cm compr.; cálice esparso barbado, margem ciliada, sépalas heteromórficas, obovadas a ovadaelípticas; corola amarela, glabra, pétalas heteromórficas, obovadas a oblanceoladas, ápice arredondado a obcordado, unguiculadas; estames 7, heterodínamos, glabros, estaminódios 3; ovário séssil, reto, seríceo, estilete encurvado, glabro. Legume estreito-oblongo a linear, reto, $5,5-11,5 \times 0,7-0,8 \mathrm{~cm}$, imaturo verde, maduro castanho, deiscente, esparso-pubescente, rostelo cêntrico, sementes 17-44, elipsóides a ovóides, castanho-esverdeadas, granuladas, areoladas. Material examinado: 4.XII.2007, fr., F.M. Alves \& A.L.B. Sartori 491 (CGMS); 4.XII.2007, fl. e fr., F.M. Alves \& A.L.B. Sartori 494 (CGMS).

Senna occidentalis tem ampla distribuição, ocorrendo desde os Estados Unidos até o noroeste e nordeste da Argentina (Irwin \& Barneby 1982), e em todo o Brasil (Pott \& Pott 1994). Ocorre em áreas degradadas de florestas, ambientes de savanas e ribeirinhos, pastagens e borda de estradas (Irwin \& Barneby 1982). S. occidentalis é facilmente diferenciada por apresentar a estrutura 


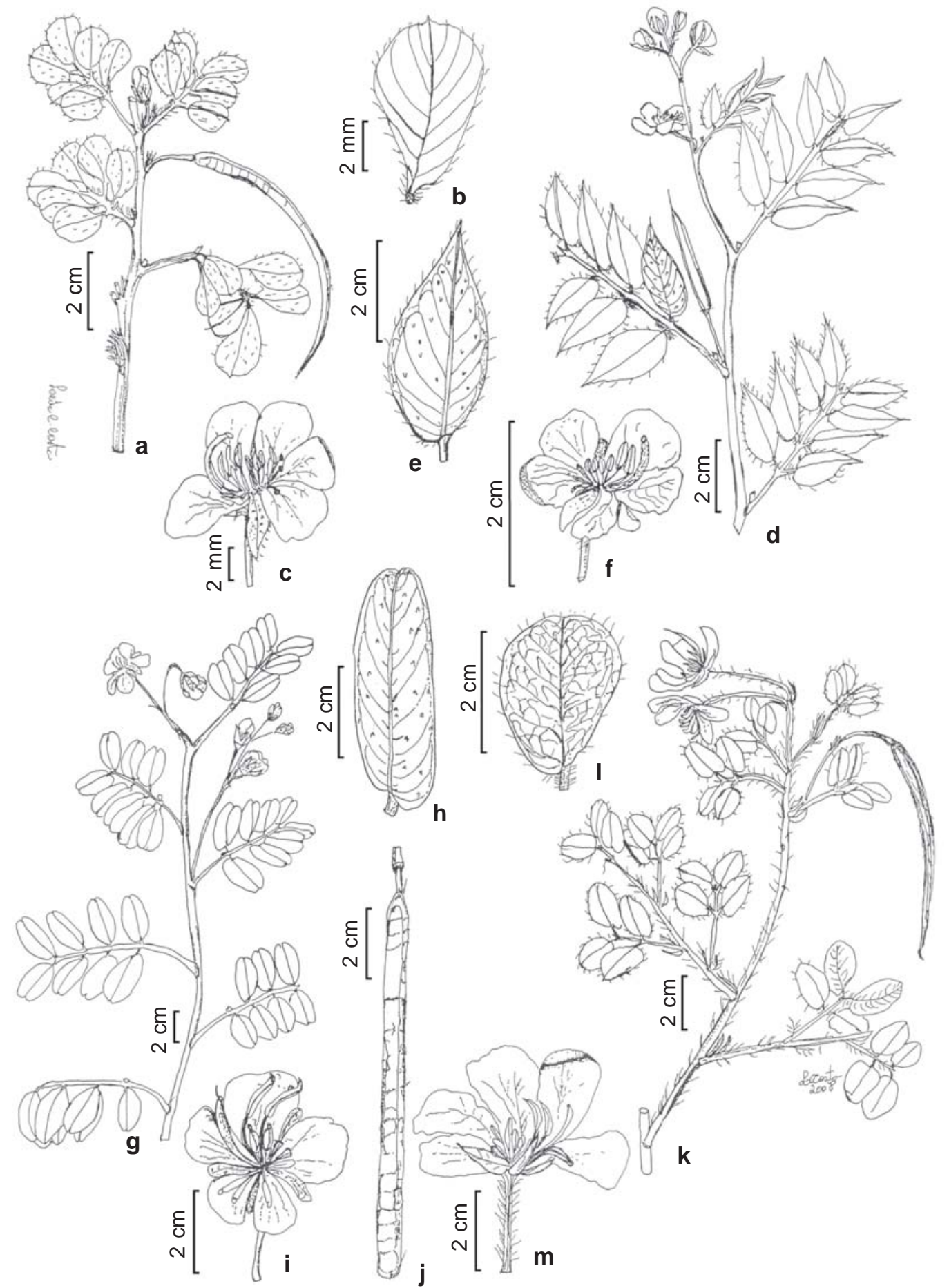

Figura 6 - a-c. Senna obtusifolia (Linnaeus) H.S. Irwin \& Barneby - a. ramo; b. folíolo; c. flor. d-f. Senna occidentalis (L.) Link Greene - d. ramo; e. folíolo; f. flor. g-j. Senna pendula (Willd.) H.S. Irwin \& Barneby var. paludicola H.S. Irwin \& Barneby - g. ramo; h. folíolo; i. flor; j. fruto. k-m. Senna pilifera var. pilifera (Vogel) Irwin \& Barneby - k. ramo; l. folíolo; m. flor (a-c Alves et al. 377; d-f Alves \& Sartori 494; g-j Alves et al. 398; k-m Alves \& Sartori 492).

Figure 6 - a-c. Senna obtusifolia (Linnaeus) H.S. Irwin \& Barneby - a. branch; b. leaflet; c. flower. d-f. Senna occidentalis (L.) Link Greene - d. branch; e. leaflet; f. flower. g-j. Senna pendula (Willd.) H.S. Irwin \& Barneby var. paludicola H.S. Irwin \& Barneby - g. branch; h. leaflet; i. flower; j. fruit. k-m. Senna pilifera var. pilifera (Vogel) Irwin \& Barneby - k. branch; l. leaflet; m. flower (a-c Alves et al. 377; d-f Alves \& Sartori 494; g-j Alves et al. 398; k-m Alves \& Sartori 492). 
secretora peciolar na base do pecíolo, 4-6 pares de folíolos, elípticos, legume estreito-oblongo a linear e reto. Espécie encontrada em áreas antropizadas do remanescente.

6.3. Senna pendula var. paludicola H.S. Irwin \& Barneby, Mem. New York Bot. Gard. 35: 393-394. 1982.

Fig. 6 g-j

Arbusto ereto, ca. 1,5-2,5 m alt.; ramo cilíndrico, estriado, inerme, glabrescente. Estípula caduca, estreito-triangular, subglabrata, margem inteira, hipódroma. Folha paripinada, 4,2-10,7 cm compr., (2-)3-4 pares de folíolos opostos, estrutura secretora peciolar capitada no primeiro par de folíolos ou próximo; pecíolo e raque dorsalmente suturados, subglabratos a pubescentes; folíolo 1,1-5,2 × 0,9-2,5 cm, glabro a subglabrato, raro barbado na base da face abaxial, ovado, elíptico, oblongo, folíolos apicais obovados, ápice geralmente retuso, raro obtuso ou agudo, base oblíqua, margem inteira ou parcamente ciliada, discolor, venação broquidódroma, nervura principal cêntrica a excêntrica. Inflorescência em racemo, axilar ou terminal, 3-9 flores; bráctea caduca, triangular, ciliada, subglabrata externamente, bractéola ausente, pedúnculo livre. Flor 2,3$5,5 \mathrm{~cm}$; cálice puberulento, margem inteira, sépalas heteromórficas, obovadas, elípticas a triangulares; corola amarela, glabra, pétalas heteromórficas, obovadas e largo-obovadas, ungüícula curta ou ausente; estames 7, heterodínamos, glabros, estaminódios 3; ovário séssil, glabrescente, estilete encurvado, glabro. Legume bacóide, $12-16 \times 0,7-0,8 \mathrm{~cm}$, linear, imaturo verde, maduro não observado, indeiscente, glabro, rostelo ausente; sementes 80-96, bisseriadas, envoltas pelo exo e mesocarpo, imaturas verde-escuro, ruminadas, reniformes assimétricas, achatadas.

Material examinado: 17.II.2007, fl., F.M. Alves et al. 40 (CGMS); 8.V.2007, fl., F.M. Alves et al. 365 (CGMS); 9.V.2007, fl. e fr., F.M. Alves et al. 398 (CGMS); 4.XII.2007, fl., F.M.Alves \& A.L.B. Sartori 499 (CGMS).

Senna pendula var. paludicola apresenta registros na Bolívia, Paraguai,
Argentina e Brasil (no Pantanal). É registrada em bordas de florestas, margens de lagoas, barrancos e gramados inundáveis (Irwin \& Barneby 1982). É facilmente reconhecida por ser a única espécie de Senna com hábito arbustivo para a região. Apresenta folhas com (2-)3-4 pares de folíolos, folíolos ovados, elípticos, oblongos, os apicais obovados, legumes bacóides pêndulos no ramo, com sementes bisseriadas. Ocorre no interior do remanescente, onde predomina o estrato arbóreo-arbustivo e herbáceo-arbustivo.

6.4. Senna pilifera (Vogel) Irwin \& Barneby var. pilifera, Mem. New York Bot. Gard. 35: 241. 1982.

Fig. 6 k-m

Subarbusto decumbente, 0,3-1 m compr., ramo cilíndrico, estriado, ápice anguloso, inerme, pubescente, hirsuto. Estípula persistente, estreito-triangular a lineartriangular, margem ciliada, hirsuta, nervação hipódroma. Folha paripinada, 3,3-5 cm, 2 pares de folíolos, opostos, estrutura secretora peciolar capitada, estipitada, entre os pares de folíolos; pecíolo e raque levemente suturados na face dorsal, hirsutos a pubescentes; folíolo 1-3 ×0,9-2 cm, glabro, subglabrato na nervura central (face abaxial), geralmente rômbico, assimétrico, ápice arredondado mucronado a emarginado, base oblíqua, margem ciliada, discolor, venação broquidódroma, nervura principal excêntrica. Inflorescência pseudoumbelada, axilar a terminal, 1-2 flores; bráctea lanceolada, ciliada, subglabrata externamente; bractéola ausente, pedúnculo livre. Flor 3,1-5,5 cm compr.; cálice glabro, margem ciliada, sépalas heteromórficas, obovadas, estreito-elípticas, ovadas; corola amarela, internamente glabra, externamente pubescente, pétalas heteromórficas, obovadas, ápice arredondado a obcordado, ungüícula ornamentada; estames 7, heterodínamos, glabros, antera apiculada; estaminódios 3; ovário séssil, seríceo, estilete levemente encurvado, seríceo. Legume linear, falcado, 9,7-15,5 ×0,3-0,35 cm, imaturo verde, maduro 
acastanhado, deiscente, esparso pubescente, rostelo cêntrico, sementes 20-31, oblongas, rombóides ou cúbicas, acastanhadas a verdeescuro, lisas ou sutilmente granuladas, areoladas.

Material examinado: 29.VIII.2007, fl.,F.M. Alves et al. 466 (CGMS); 4.XII.2007, fl. e fr., F.M. Alves \& A.L.B. Sartori 492 (CGMS).

Senna pilifera var. pilifera distribui-se de acordo com Irwin \& Barneby (1982) na bacia Paraná-Paraguai da Bolívia, Paraguai, Argentina e Brasil (sul, sudeste e centro-oeste). Ocorre em áreas de campo, pastagens, brejos inundáveis, cerrado perturbado, borda de estradas e florestas em regeneração (Irwin \& Barneby 1982). É caracterizada por hábito subarbustivo decumbente, folhas com dois pares de folíolos, estrutura secretora capitada estipitada entre os pares de folíolos, folíolos geralmente rômbicos e assimétricos. Na área de estudo, as populações desta espécie ocorrem entre os estratos arbustivo-arbóreos e herbáceos, principalmente no interior do remanescente.

\section{Tribo Cercideae Bronn}

\section{Bauhinia L.}

Árvores ou arbustos (Lewis et al. 2005); folhas simples ou bifolioladas (Fortunato 1986; Bortoluzzi et al. 2006), presença de almofada motora na base dos folíolos, peciólulos indistintos (Vaz \& Tozzi 2003), 10 estames em dois verticilos (Fortunato 1986; Bortoluzzi 2006). Bauhinia s.s. é pantropical, contém ca. 160 espécies, sendo que 75 ocorrem na América do Sul (Lewis et al. 2005). Para este trabalho foi registrada apenas Bauhinia hagenbeckii.

7.1. Bauhinia hagenbeckii Harms, Bot. Jahrb. Syst. 33(72):21. 1903.

Fig. 7

Arbusto ereto, ca. 0,3-1,5 m alt.; ramo cilíndrico, estriado, armado, glabrescente, lenticelado. Estípula triangular pubescente, hipódroma. Folha bifoliolada a unifoliolada bilobada, 2,2-9,3 cm compr., estrutura secretora ausente, ápice mucronado, base cordada; pecíolo levemente suturado na face dorsal, pubescente; folíolo 1,4-7,3 × 0,7$2,8 \mathrm{~cm}$, face adaxial glabra, face abaxial curto pubescente, oblongo, ovado a obovado, base oblíqua, ápice agudo, obtuso ou arredondado, margem inteira, discolor, venação palmatinérvea, 3 ou 4 nervuras primárias. Inflorescência em racemo, supra-axilar, 1-2 flores; bráctea não observada, 3 bractéolas triangulares, pubescentes; pedúnculo adnato ao ramo. Flor 5,1-7,6 cm compr.; cálice puberulento adpresso, 2-3 lobos, margem inteira, sépalas isomórficas, lineares; corola branco-esverdeada, vilosa, pétalas isomórficas, lineares, ápice acuminado, ungüiculadas; estames 10 , heterodínamos, viloso na face dorsal e glabro na face ventral da coluna de estames; ovário amplamente estipitado, glabro a glabrato, estilete reto, glabro, estípite barbada na base. Legume estreito-oblongo a estreitoobovado, tendendo a linear, (7,4-)10,3-14,8 $\times$ 0,9-1,3 cm, imaturo verde, maduro castanho, deiscente, subglabrato, rostelo cêntrico a levemente excêntrico, sementes 11-16, ovóides a largo-elipsóides, achatadas, castanhas, borda espessa, linealatas.

Material examinado: 16.II.2007, fr., F.M. Alves et al. 12 (CGMS); 17.II.2007, fl. e fr., F.M. Alves et al. 33 (CGMS); 17.II.2007, fl. e fr., F.M. Alves et al. 61 (CGMS); 17.II.2007, fl. e fr., F.M. Alves et al. 275 (CGMS); 8.V.2007, fl. e fr., F.M. Alves et al. 375 (CGMS); 3.XII.2007, fl. e fr., F.M. Alves \& A.L.B. Sartori 73 (CGMS); 3.XII.2007, fl., F.M. Alves \& A.L.B. Sartori 74; 5.XII.2007 (CGMS), fl., A.L.B. Sartori \& F.M. Alves 1084 (CGMS).

Bauhinia hagenbeckii segundo Wuderlin (1968) e Vaz \& Tozzi (2005) é citada para o "Gran Chaco" brasileiro e paraguaio (Amambay, Boqueron e Cordilleiras), contudo, sem informação precisa do local de ocorrência em território nacional. É caracterizada por apresentar acúleos na base das folhas, as folhas bifolioladas ou unifolioladas bilobadas, flores com cálice gamossépalo, corola brancoesverdeada vilosa, androceu gamostêmone. $\mathrm{Na}$ área de estudo é comumente encontrada em locais de vegetação arbórea-arbustiva esparsa e na borda do remanescente. 


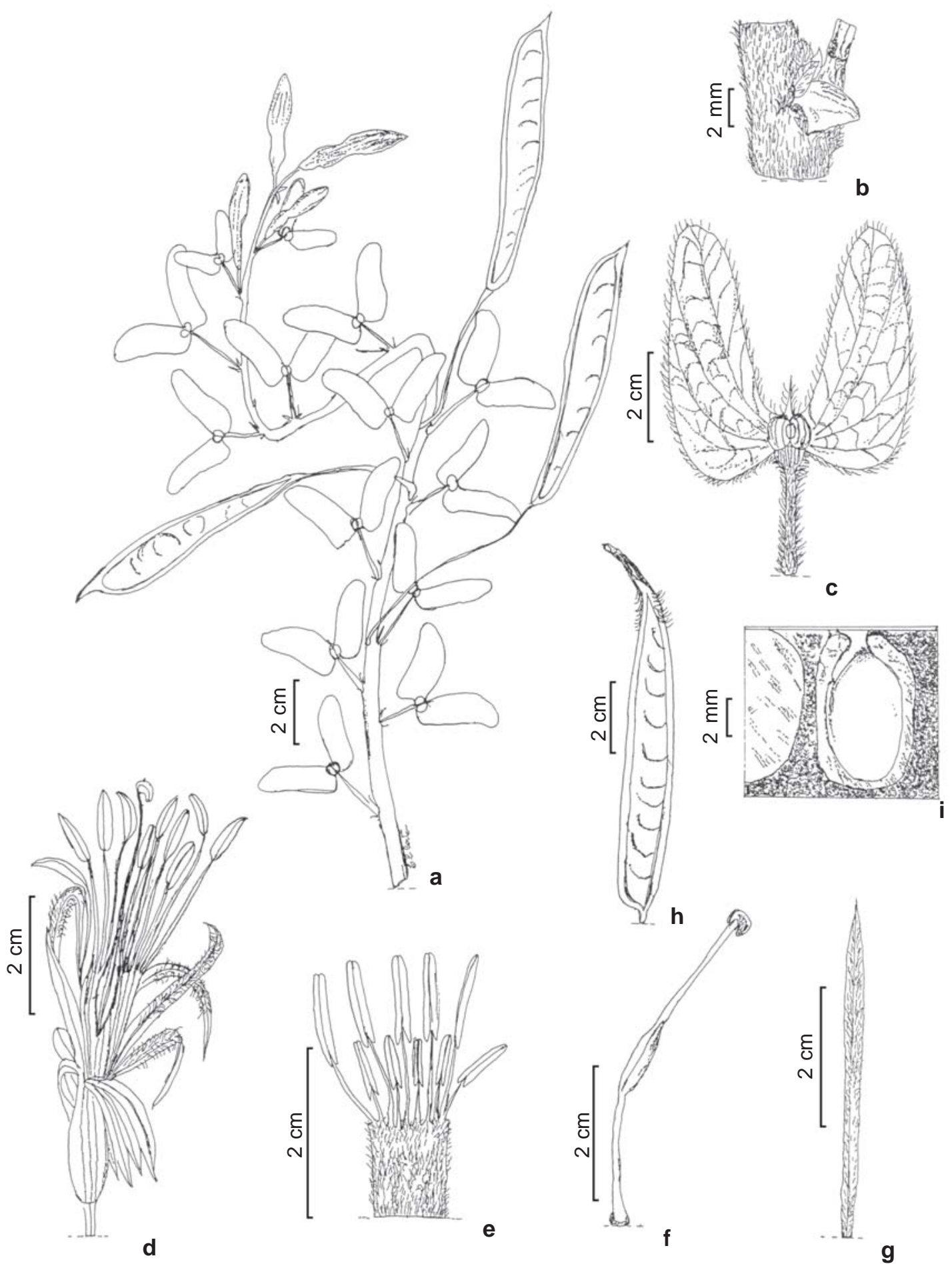

Figura 7 - Bauhinia hagenbeckii Harms - a. ramo; b. acúleo; c. folha; d. flor ; e. estames; f. carpelo; g. pétala; h. fruto; i. semente com inserção no fruto (a-i Alves et al. 275).

Figure 7 - Bauhinia hagenbeckii Harms - a. branch; b. aculeus; c. leaf; d. flower ; e. stamen; f. gynoecium; g. petal; h. fruit; i. detail of fruit, showing the seeds (a-i Alves et al. 275). 


\section{Agradecimentos}

Os autores agradecem a Pró-Reitoria de Pesquisas e Pós Graduação da UFMS pelo custeio das expedições de campo. Ao Sr. Nelson Cintra (prefeito de Porto Murtinho) pela logística para os trabalhos de campo. A FUNDECT/CAPES (Fundação de Apoio ao Desenvolvimento do Ensino, Ciência e Tecnologia do Estado de Mato Grosso do Sul/ Coordenação de Aperfeiçoamento de Pessoal de Nível Superior) pela concessão da bolsa de estudos ao primeiro autor. Aos especialistas Haroldo Cavalcante de Lima (Caesalpinia), Geciani Miriam Silva (Bauhinia de MS) e Ângela Maria Studart da Fonseca Vaz (Bauhinia). A Leila Carvalho da Costa pelas ilustrações botânicas.

\section{REFERÊNCIAS BIBLIOGRÁFICAS}

Adamoli, J.; Newman, R.; Colina, A. D. R. \& Morello, J.1972. El Chaco aluvional salteño. Revista de Investigaciones Agropecuárias 9(5): 165-237.

Bacigalupo, N. M. 1987. Leguminosae. In: Burkart, A. (coord.). Flora ilustrada de Entre Rios. Pt. 3. INTA, Buenos Aires. Pp. 442-738.

Barneby, R. C. 1996. Neotropical Fabales at NY: asides e oversights. Brittonia 48(2): 174-187.

Barroso, G. M.; Morim, M. P.; Peixoto, A. L. \& Ichaso, C. L. F. 1999. Frutos e sementes. Morfologia aplicada à sistemática de dicotiledôneas. Universidade Federal de Viçosa, Viçosa. 443p.

Bortoluzzi, R. L. C.; Miotto, S. T. S. \& Reis, A. 2006. Leguminosas caesalpinioídeas. In: Reis, A. Flora Ilustrada Catarinense, I parte, fascículo LEGU 2: 1-96.

Burkart, A. \& Carter, A. 1976. Notas en el género Cercidium (Caesalpinioideae) en Sur América. Darwiniana 20(3-4): 305-311.

Camargo, R. A. \& Miotto, S. T. S. 2004. O gênero Chamaecrista Moench (Leguminosae-Caesalpinioideae) no Rio Grande do Sul. Iheringia 59(2): 131-148.
Dubs, B. 1998. Leguminosae-Caesalpinioideae. In: Prodromus florae matogrossensis. Betrona Verlag, Kusnacht. Pp. 140-148.

Fernandes, A. 2003. Relacionamentos florísticos. In: Conexões florísticas do Brasil. Ed. Banco do Nordeste, Fortaleza. Pp. 61-122.

Fidalgo, O. \& Bononi, V. L. R. 1984. Técnicas de coleta, preservação e herborização do material botânico. Instituto de Botânica (manual 4), São Paulo. 61p.

Fortunato, R. H. 1986. Revision del gênero Bauhinia (Cercideae, Caesalpinioidea, Fabaceae) para la Argentina. Darwiniana. 27(1-4): 527-557.

Guedes-Bruni, R. R.; Morim, M. P.; Lima, H. C. \& Sylvestre, L. S. 2002. Inventário florístico. In: Sylvestre, L. S \& Rosa, M. M. T. (orgs.). Manual metodológico para estudos botânicos na Mata Atlântica. Seropédica, Rio de Janeiro. Pp. 24-49.

Hawkins, J. A.; Olascoaga, L. W.; Hughes, C. E.; Jimenéz, J-L. R. C. \& Ruaro, P. M. 1999. Investigation and documentation of hybridization between Parkinsonia aculeata and Cercidium praecox (Leguminosae: Caesalpinioideae). Plant Systematics and Evolution 216: 49-68.

Hueck, K. 1972. As regiões de matas do Chaco e áreas marginais. In: Azevedo, J. C. A.; Anjos, C. V.; Gomes, L. C.; Lyra Filho, R.; Moraes, R. B.; Paraense, W. L. \& Fonseca, E. N. (eds.). As florestas da América do Sul: ecologia, composição e importância econômica. Editora Polígono, Brasília. Pp. 240-275.

IBGE. 1992. Manual técnico da vegetação brasileira. Fundação Instituto Brasileiro de Geografia e Estatística, Rio de Janeiro, 89p.

Irwin, H. S. \& Barneby, R. C. 1982. The American Cassiinae: a synoptical revision of Leguminosae tribe Cassieae subtribe Cassineae in the New World. Memoirs of the New York Botanical Garden 35(12): 1-918.

Killeen, T. J.; Chavez, E.; Peña-Claros, M.; Toledo, M.; Arroyo, L.; Saldias, M.; Soria, 
L.; Uslar, Y.; Vargas, I. \& Steininger, M. 2006. The Chiquitano dry forest, the transition between humid and dry forest in eastern lowland Bolivia. In: Pennington, R. T.; Lewis, G. P. \& Ratter, J. A. (eds.). Neotropical savannas and seasonally dry forests: plant diversity, biogeography, and conservation, n69. CRC Press - Taylor \& Francis Group, London. Pp. 213-233.

Lewis, G. P.; Schrire, B.; Mackinder, B. \& Lock, M. 2005. Legumes of the world. Royal Botanic Gardens, Kew. 577p.

Lewis, J. P. 1991. Three levels of floristical variation in the forests of Chaco, Argentina. Journal of Vegetation Science 2: 125-130.

Nunes, G. P. 2006. Estudo florístico de formações chaquenhas brasileiras e caracterização estrutural de um remanescente de Chaco de Porto Murtinho, MS, Brasil. Dissertação de Mestrado. Universidade Federal de Mato Grosso do Sul, Campo Grande. 77p.

Prado, D. E.; Gibbs, P. E.; Pott, A. \& Pott, V. J. 1992. The Chaco-Pantanal transition in southern Mato Grosso, Brazil. In: Furley, P. A.; Proctor, J. \& Ratter, J. A. (eds.). Nature and Dynamics of Forest-Savanna Boundaries. Chapman \& Hall, London. Pp. 451-470.

Prado, D. E. \& Gibbs, P. E. 1993. Patterns of species distributions in the dry seasonal forests of South America. Annals of the Missouri Botanical Garden 80(4): 902-927.

Pott, A. \& Pott, V. J. 1994. Plantas do Pantanal. EMBRAPA, Corumbá. 320 p.

Pott, A. \& Pott, V. J. 2003. Espécies de fragmentos florestais em Mato Grosso do Sul. In: Costa, R. B. (org.). Fragmentação florestal e alternativas de desenvolvimento rural na região Centro-Oeste. UCDB, Campo Grande. Pp. 26-52.
Pott, A.; Pott, V. J.; Sciamarelli, A.; Sartori, A. L. B.; Resende, U. M.; Scremin-Dias, E.; Jacques, E. L.; Aragaki, S.; Nakajima, J. N.; Romero, R.; Cristaldo, A. C. M. \& Damasceno-Junior. G. A. 2006. Inventário de angiospermas no Complexo AporéSucuriú. In: Paggoto, T.C.S \& Souza, P.R. (orgs.) Biodiversidade do Complexo Aporé-Sucuriú: subsídios à conservação e ao manejo do Cerrado. UFMS, Campo Grande. Pp. 45-66.

Radford, A. E.; Dickson, W. C.; Massey, J. R. \& Bell, C. R. 1974. Vascular plant systematics. Harper \& Row, New York. 891p.

Rizzini, C. T. 1977. Sistematização terminológica da folha. Rodriguésia 29(42): 103-125.

Spichiger, R.; Ramella, L.; Palese, R. \& Mereles, F. 1991. Proposición de leyenda para la cartografía de las formaciones vegetales del Chaco paraguayo, Contribución al estudio de la flora y de la vegetación del Chaco. III. Candollea 46: 541-564.

Stearn, W. T. 2004. Botanical Latin. 4a ed. Timber Press, Portland. 546p.

Ulibarri, E. 1996. Sinopsis de Caesalpinia y Hoffmannseggia (LeguminosaeCaesalpinioideae) de Sudamérica. Darwiniana 34: 299-348.

Vaz, A. M. S. F. \& Tozzi, A. M. G. A. 2003. Bauhinia ser. Cansenia (Leguminosae: Caesalpinioideae) no Brasil. Rodriguésia 54(83): 55-143.

Vaz, A. M. S. F. \& Tozzi, A. M. G. A. 2005. Sinopse de Bauhinia sect. Pauletia (Cav.) DC. (Leguminosae: Caesalpinioideae: Cercideae) no Brasil. Revista Brasileira de Botânica 28(3): 477-491.

Wunderlin, R.P. 1968. A note on Bauhinia hagenbeckii Harms. Phytologia 17(3): 245-246. 